\title{
Effect of Ghaggar River on the underground water of Sirsa (Haryana): A Study on physicochemical parameters
}

\author{
Rajender Kumar ${ }^{1}$, Ashutosh Pathak ${ }^{1,}$ Pawanvir Kaur $^{2}$ \& Harish Kumar ${ }^{3, *}$ \\ ${ }^{1}$ Dept. of Chemistry, Guru Kashi University, Talwandi Sabo, Punjab. \\ ${ }^{2}$ Dept. of Chemistry, govt. National College, Sirsa. \\ ${ }^{3}$ Dept. of Chemistry, CUH, Mahendergarh, Haryana. \\ *Author for correspondence: harimoudgil1@gmail.com
}

\begin{abstract}
Water pollution is a very serious concern nowadays because the quality of water we drink affects our health. Groundwater quality is decreasing day by day due to its excessive use in agriculture, industrial sectors, and amusement parks. Water quality parameters of groundwater need to be continuously monitored. We have analyzed sixteen water quality parameters of underground water of different regions of Sirsa district like Jhopra, Vaidwala, Begu, Mirpur, and Bajekan (sampling period June 2020 to May 2021). The sixteen physicochemical parameters like $\mathrm{pH}$, conductivity, TDS, alkalinity, turbidity, heavy metals, $B O D$, $C O D$, hardness, Nitrates, phosphates, sulfates, elements like $\mathrm{Fe}, \mathrm{Cu}, \mathrm{Cr}, \mathrm{Pb}, \mathrm{Na}, \mathrm{K}$, etc. were analyzed using a pH meter, conductivity meter, AAS, Flame photometer, UV-visible spectrophotometer, and turbidity meter. The water quality index was calculated for the complete year focussing on the evaluation of an average value of biological, chemical, and physical parameters. The water quality index of the geographical and socioeconomic important region i.e., Sirsa was explored by random selection of five different regions. The different physicochemical parameters were compared with WHO standards.
\end{abstract}

Keywords: Physicochemical parameters, Alkalinity, hardness, BOD, TDS, Water quality index. 


\section{Introduction}

Seventy percent of our earth's surface is covered with water. Despite that pure and safe drinking water available is only $1 \%$. Most of the water resent in sea and glacier is not suitable for drinking and other irrigation purposes. Further, groundwater level at some places is gone so deep that it is not available easily. Even if water at some places present at a suitable height is not fit for drinking purposes. Drinking water quality can be judged by different physicochemical parameters like $\mathrm{pH}$, conductivity, TDS, alkalinity, turbidity, heavy metals, BOD, COD, hardness, etc. [1-5]. WHO has fixed a certain acceptable range of different physiochemical parameters of drinking water. A tremendous increase in population, urbanization, industry, and agricultural water requirement, leads to very serious safe and pure drinking water problems among us. Water is very essential for both plants as well as a human being. No one can even think of life without water. Water is very essential in shaping human, land, and climate life. During the past few years, there is a huge demand for a large amount of freshwater due to the burst in population and increase in industrial activities due to growth in industrial civilization [6].

The quality of water has a very large impact on agriculture and human being. It is very essential to know the quality of water to be supplied for drinking and irrigation purposes [7-9]. There is an urgent requirement for the proper identification of pure and safe drinking water in different parts of the earth's crust. Few heavy metals, beyond their acceptable range, enter our food chain may lead to serious disorders [10-12]. The Sirsa district of Haryana touches the boundary of two states that is Rajasthan and Punjab and hence the influence of the three states. Sirsa district of Haryana has geographical, historical, political (SC reserved constituency), religious, and sociocultural importance making a different district in Haryana state. The underground water of Sirsa district is mainly dependent on rain, and the Ghaggar river (popularly called as Barssatti river). The chemical substance present in underground water like trace elements, heavy metals, detergents, pesticides, petroleum products, acidic and basic impurity, etc. affects the quality of water [13]. Similarly, physical parameters like temperature, $\mathrm{pH}$, color, turbidity, etc. also affect the quality of water. Similarly, the presence of biological parameters like bacteria, viruses, spores, pigments, phytoplankton, BOD, COD, dissolved oxygen, etc. also affects the quality of the underground water [14]. The huge demand for underground water for drinking, agriculture, industrial, purposes, improper sewerage facilities, and improper water management facility leads to change in the chemical, physical, and biological composition of underground water [15]. The link between population, climate, and ecology must be understood to have a balance between the three so that our ecosystem and biodiversity should not be disturbed.

In the present study, we have investigated the effects of human activities on qualities of underground water of geographical, historical, political, religious, and sociocultural important districts of Haryana i.e., Sirsa. We have estimated sixteen physiochemical parameters like $\mathrm{pH}$, conductivity, TDS, alkalinity, turbidity, heavy metals, BOD, COD, hardness, Nitrates, phosphates, sulfates, elements like $\mathrm{Fe}, \mathrm{Cu}, \mathrm{Cr}, \mathrm{Pb}, \mathrm{Na}$, K, etc. of underground water of four villages of Sirsa district (Haryana) and compared our data with WHO standard parameters. 
Based on our study, one can conclude whether the underground water of these villages is fit for drinking and irrigation purposes or not? Our research is directly related to the benefit of the society so that people of that area become aware of the ground water quality of that area so that they can plan their agricultural production accordingly.

\section{Materials and Methods:}

$100 \mathrm{ml}$ of underground water was collected in PVC sample bottles from four villages of Sirsa district i.e., Jhopra, Vaidwala, Begu, Mirpur, and Bajekan from the tube well source. The first fraction of water was discarded. Then water was collected in a 251 capacity plastic bucket. Water was allowed to stand for some time. Then $100 \mathrm{ml}$ of water was collected in a sample bottle at $10 \mathrm{~cm}$ below the water level. The precaution was kept in mind that water gets disturbed at a minimum level so that amount of dissolved oxygen must not change while sampling the underground water.

\section{Total Hardness:}

Procedure: In a $20 \mathrm{ml}$ sample of groundwater, a $5 \mathrm{ml}$ buffer solution $\left(\mathrm{NH}_{4} \mathrm{Cl}\right.$ and $\left.\mathrm{NH}_{4} \mathrm{OH}\right)$ was added followed by a few drops of Eriochrome Black T (EBT) indicator. The blue color appeared in the buffered solution at $\mathrm{pH}$ 10. It turns red, on complexation with calcium, magnesium, or other metal ions. After adding EBT, the wine-red color appears. $10 \mathrm{ml}$ of this solution was titrated with $0.1 \mathrm{M}$ Ethylene diamine tetraacetic acid (EDTA) till the endpoint (appearance of blue color). Titrations were repeated three times [16-19].

\section{Permanent Hardness:}

Selected $100 \mathrm{ml}$ groundwater from five different regions of Sirsa district. Now heat the given sample until it becomes half in volume. The sample was filtered with ordinary filter paper. Added $50 \mathrm{ml}$ of distilled water. To $20 \mathrm{ml}$ of this solution, $5 \mathrm{ml}$ buffer solution $\left(\mathrm{NH}_{4} \mathrm{Cl}+\right.$ $\mathrm{NH}_{4} \mathrm{OH}$ ) with Eriochrome Black-T (EBT) as indicator was added. Then it was titrated with 0.1 M EDTA till the endpoint (appearance of blue color) [20-21].

Temporary Hardness: = Total Hardness - Permanent Hardness.

\section{p-alkalinity:}

In $20 \mathrm{ml}$ of groundwater, 2-3 drops of Phenolphthalein indicator were added. Then it was titrated with $0.1 \mathrm{~N} \mathrm{HCl}$ solution. After titration, the color changes from light pink to colorless due to the acidic medium of $\mathrm{HCl}[22]$.

\section{m-Alkalinity:}

In $20 \mathrm{ml}$ of underground water, 2-3 drops of Methyl orange indicator were added. Then it was titrated with $0.1 \mathrm{~N} \mathrm{HCl}$ solution. At the endpoint, the color changes from yellow to red [23].

Total Alkalinity = p-Alkalinity + m-Alkalinity.

\section{Dissolved Oxygen:}

Chemicals used: Manganese Sulphate $\left(\mathrm{MnSO}_{4}\right)$, Alkali Iodide Azide, Sulphuric Acid, Starch, $\mathrm{Na}_{2} \mathrm{~S}_{2} \mathrm{O}_{3} . \mathrm{xH}_{2} \mathrm{O}$. 
Procedure: In a $100 \mathrm{ml}$ underground water sample, $0.68 \mathrm{~g}$ of $\mathrm{MnSO}_{4}$ was added followed by $2 \mathrm{ml}$ of alkali iodide azide. Then $2 \mathrm{ml} \mathrm{H}_{2} \mathrm{SO}_{4}$ of dilute sulphuric acid was added. The resultant solution was titrated with Sodium thiosulphate till the appearance of pale yellow color. 2 $\mathrm{ml}$ of starch solution was added. The solution becomes blue. Now titrated continuously till the blue color disappears [24-26].

\section{Test for COD (Chemical Oxygen demand):}

Preparation: $3.5 \mathrm{~g}$ of $\mathrm{FeSO}_{4} .7 \mathrm{H}_{2} \mathrm{O}$ and $7.5 \mathrm{~g}$ of $\mathrm{C}_{12} \mathrm{H}_{8} \mathrm{~N}_{2} . \mathrm{H}_{2} \mathrm{O}$ were added to $400 \mathrm{ml}$ of water (double distilled). Mixed properly and the total volume was made to $500 \mathrm{ml}$ by adding distilled water.

Procedure (COD): $10 \mathrm{ml}$ of underground water sample was taken in a RB flask. $\mathrm{Few}$ glass beads were added. One $\mathrm{ml} \mathrm{of} \mathrm{Hg}_{2} \mathrm{SO}_{4}$ solution was added. Add $5 \mathrm{ml}$ of potassium dichromate solution. $15 \mathrm{ml}$ silver sulfate and dilute sulphuric acid solution was added very slowly and carefully. It was then refluxed for $2 \mathrm{~h}$. After digestion, the condenser was rinsed with $25 \mathrm{ml}$ of water. Add 2-4 drops of ferroin indicator and titrate with $0.025 \mathrm{M}$ ferrous ammonium sulfate solution till the endpoint. Make the blank preparation in the same manner as the sample using distilled water instead of the sample [27].

\section{BOD: (Biochemical Oxygen Demand)}

The material used: Alkaline iodide-azide solution, Manganese sulfate, Sulphuric acid, Starch solution $0.025 \mathrm{~N}$ sodium thiosulphate.

Procedure: In $100 \mathrm{ml}$ of the underground water sample, $2 \mathrm{ml}$ of manganese sulfate was added to the BOD bottle carefully by inserting the pipette just below the surface water. 2 $\mathrm{ml}$ of alkali-iodide-azide reagent was added in the same manner. "Close the bottle and mix the sample by inverting it many times. A brownish cloud will appear in the solution as an indicator of the presence of dissolved oxygen. Allow the brown precipitate to settle. Add $2 \mathrm{ml}$ of sulphuric acid carefully without forming air bubbles. Close to the bottle and mix the solution well to dissolve the precipitate. Keep the bottle in a BOD incubator for 5 days of incubation. After incubation, titrate $50 \mathrm{ml}$ of sample water with $0.025 \mathrm{~N}$ sodium thiosulphate to a pale yellow color. Then add $2 \mathrm{ml}$ of starch solution. So, the samples turn in blue. Continue the titration till the sample gets clear and note down the reading. The concentration of dissolved oxygen in the sample is equivalent to the number of milliliters of titrant used" [28].

\section{Results and Discussion}

Water is very essential for sustaining life on the earth. Water used for drinking and irrigation purposes should be clean, pure, and should be free from impurities. But due to a large number of industrial and other developmental activities water available for drinking and agricultural purposes is being polluted constantly. There are different sources of water like rainwater, river water, pond water, groundwater, seawater, etc. The quality of water (Physical, Chemical, and biological) varies a lot depending upon the source of water. Seawater is not fit for drinking and agriculture purposes due to a large number of dissolved salts $(3 \% \mathrm{NaCl})$ makes it unfit for use. The quality of groundwater also varies a lot from place to place. The quantity of groundwater is also decreasing day by day. The groundwater level is also going down day by day and in 
some places in Haryana state, groundwater is available at 500 feet. It is very essential to know the effects of the addition of pesticides in the fields on the groundwater quality, heavy metal contents in groundwater, and effects of industrial influents on the quality of underground water in Sirsa district.

Parameters like temperature, $\mathrm{pH}$, Electrical conductivity, total dissolved solids, $\mathrm{Ca}, \mathrm{Mg}, \mathrm{K}, \mathrm{Na}$, $\mathrm{CO}_{3}, \mathrm{HCO}_{3}$, chloride, $\mathrm{SO}_{4}, \mathrm{NO}_{3}$, total hardness as $\mathrm{CaCO}_{3}$, Fluoride, $\mathrm{Fe}, \mathrm{Pb}, \mathrm{Zn}, \mathrm{Cd}, \mathrm{Mn}$, Heavy metal ions, alkalinity, biochemical oxygen demand, chemical oxygen demand, transition metal cation, etc. needs to be estimated in the rural and urban district of Sirsa (Haryana). The water quality index was calculated by the use of Eq. (1) [29-31]:

$$
W Q I=\sum_{i=1}^{p} W_{i} L_{i}
$$

Where WQI is water quality analysis, $W_{i}$ is the statistical weight and $L_{i}$ is the water quality parameter observed for different underground water samples, and $p$ is the number of water quality parameters [].

The underground water quality rating was calculated by the use of Eq. (2) $[32,33]$ :

$$
q_{r}=\left\{\left[\frac{V_{\text {actual }}-V_{\text {ideal }}}{V_{\text {standard }}-V_{\text {ideal }}}\right] \times 100\right\}
$$

The ideal value of dissolved oxygen and $\mathrm{pH}$ were taken to be 14.6 and 7, respectively. The standard value of parameters was taken as suggested by WHO.

The overall water quality parameters index was calculated by the use of Eq. (3) [34]:

$$
O W Q I=\sum \frac{q_{i} W_{i}}{W_{i}}
$$

Here, OWQI stands for the overall water quality index.

Table 1 shows standard values of the water quality index as prescribed by the Central Pollution control board. Table 2 shows Flame Photometric and UV-VIS spectrophotometric evidence of underground water of different villages of Sirsa district. Sodium metal concentration was found maximum in underground water of Begu village $(74.2 \mathrm{ppm})$ and minimum in Vaidwala. According to the $\mathrm{WHO}$, the maximum permissible limit of Sodium in underground water is $200 \mathrm{mg} / \mathrm{l}$.

The potassium metal was found maximum in Vaidwala $(4.9 \mathrm{ppm})$ and minimum in Jhopra village. The WHO requirement of maximum Potassium content in underground water is 50 $\mathrm{mg} / \mathrm{l}$. The optical density of nitrate was found maximum in Begu (2.73) and minimum in Jhopra village. The optical density phosphate was found maximum in Begu (0.36) and minimum in Vaidwala village. The optical density of sulfate was found maximum in Begu (1.13) and minimum in Jhopra village. The WHO requirement of Nitrates in underground water is 2.5 $\mu \mathrm{g} / \mathrm{l}$. Similarly, the WHO requirements of Phosphate are $0.5 \mu \mathrm{g} / \mathrm{l}$. The WHO requirements are sulfate is $1.1 \mu \mathrm{g} / \mathrm{l}[35]$.

Table 3 shows the average value of Physico-chemical parameters $(\mathrm{pH}$, conductivity, TDS, and Turbidity) of five different villages underground water samples of Sirsa district. The average $\mathrm{pH}$ was found maximum in Vaidwala (8.25) and minimum in Bajenkan village (7.73). The 
WHO requirements of underground water $\mathrm{pH}$ range is 6.5-8.5. The order of conductivity was almost similar with somewhat higher in Vaidwala $(283.2 \mu \mathrm{S} / \mathrm{m})$ and minimum in Jhopra village $(203 \mu \mathrm{S} / \mathrm{m})$. The WHO requirements of maximum permissible limit of conductivity are 250 $\mathrm{S} / \mathrm{cm}$. The average TDS was found to be maximum in Vaidwala village i.e., $335.4 \mathrm{ppm}$, and minimum in Mirpur village (234.8 ppm). The WHO recommended level of TDS in underground water is $300 \mathrm{mg} / \mathrm{l}$ for good and $300-600 \mathrm{mg} / \mathrm{l}$ is fare and $600-900 \mathrm{mg}$ is poor. The average turbidity was found maximum in Begu (180.6 NTU) and minimum i.e., 15 NTU in Jhopra village. The WHO requirement of turbidity in underground water is 4-5 NTU [36, 37].

Table 4 shows atomic absorbance spectroscopy (AAS) analysis of underground water samples of five different villages of Sirsa district. The elemental iron was found to be similar in Jhopra and Bajekan villages and Vaidwala and Begu i.e., 0.259 and 0.159, respectively. The element copper was not detected in the underground water of the villages under study. The element chromium was detected only in two villages (Begu and Mirpur) with the same concentration i.e., 1.723. The element lead was found maximum in Bajekan and minimum in Jhopra village. Table 5 shows volumetric titration analysis (Hardness) of different underground water samples of the Sirsa district. The total hardness was found maximum in Bajekan (350 ppm) and minimum in Mirpur village (150 ppm) of Sirsa district. The permanent hardness was found maximum in the underground water of Bajenkan and minimum in Jhopra village i.e., $100 \mathrm{ppm}$. The WHO requirements for the recommended hardness of underground water are 200-600 $\mathrm{mg} / \mathrm{l}$.

Table 6 shows volumetric titration analysis (Alkalinity) of different underground water samples of the Sirsa district. The total alkalinity was found to be maximum in Begu village i.e., 24 $\mathrm{mEq} / \mathrm{l}$, and minimum in Mirpur village $(16 \mathrm{mEq} / \mathrm{l})$. The WHO requirements of alkalinity in the underground water sample is $200-600 \mathrm{mg} / \mathrm{l}$.

Table 7 shows volumetric titration analysis (dissolved oxygen) of different underground water samples of the Sirsa district. The dissolved oxygen $(\mathrm{ml})$ was found to be maximum in Jhopra village $(0.8 \mathrm{ml})$ and minimum in Vaidwala village $(0.1 \mathrm{ml})$. The WHO requirements of recommended dissolved oxygen in the underground water sample are $2-5 \mathrm{mg} / \mathrm{l}$. Table 8 shows seasonal variation in physiochemical parameters, standard deviation, and Water Quality Index (WQI) of Jhopra village of Sirsa district. The $\mathrm{pH}$ was found maximum in May 2021 and minimum in February 2021. The temperature of underground water was found maximum in June $2020\left(25^{\circ} \mathrm{C}\right)$ and minimum in February 2021. The hardness was found maximum in June 2020 i.e., 315 ppm, and minimum in February 2021 i.e., 285 ppm. The TDS was found maximum in February 2021 i.e., 237 ppm, and minimum in June 2020 i.e., 230 ppm. Table 9 seasonal variation in physiochemical parameters, standard deviation, and underground Water Quality Index of Vaidwala village of Sirsa district. The $\mathrm{pH}$ was found maximum in May 2021 (8.6) and minimum in Feb. 2021 (7.7). The hardness was found to be maximum in Feb. 2021 (265 ppm) and minimum in April 2021. The TDS was found maximum in Dec. 2020 and minimum in June 2020 (330 ppm). Table 10 shows seasonal variation in physiochemical parameters, standard deviation, and underground Water Quality Index of Begu village of Sirsa 
district. The pH was found maximum in Dec. 2020 (8.40) and minimum in Feb. 2021 (7.2). The hardness was found maximum in Dec. 2020 (253) and minimum in June 2020 (247 ppm). The TDS was found maximum in Dec. 2020 (238 ppm) and minimum in August 2020 (233 ppm).

Table 11 shows seasonal variation in physiochemical parameters, standard deviation, and underground Water Quality Index of Mirpur village of Sirsa district. The $\mathrm{pH}$ was found maximum in August 2020 (8.5) and minimum in Feb. 2021 (7.4). The hardness was found maximum in June 2020 (253) and minimum in April 2021 (147 ppm). The TDS was found maximum in Feb. 2021 (237 ppm) and minimum in October 2020 (172 ppm). Table 12 shows seasonal variation in physiochemical parameters, standard deviation, and underground Water Quality Index of Bajenkan village of Sirsa district. The $\mathrm{pH}$ was found maximum in August 2020 (8.5) and minimum in Feb. 2021 (7.3). The hardness was found maximum in June 2020 (353) and minimum in April 2021 (347 ppm). The TDS was found maximum in Dec. 2021 (243 ppm) and minimum in June 2020 (237 ppm).

Fig. 2 shows the average Physico-chemical parameters of underground water of Jhopra village of Sirsa district. The magnitude of hardness was maximum followed by the TDS parameter. The magnitude of dissolved oxygen was found to be the minimum of all the seven investigated physicochemical parameters of Jhopra village. Fig. 3 shows the average Physico-chemical parameters of underground water of Vaidwala village of Sirsa district. The magnitude of TDS was maximum followed by the hardness parameter. The magnitude of dissolved oxygen was found to be the minimum of all the seven investigated physicochemical parameters of Vaidwala village. Fig. 4 shows the average Physico-chemical parameters of underground water of Begu village of Sirsa district. The magnitude of TDS and Hardness was found to be almost the same maximum followed by the turbidity parameter. The magnitude of dissolved oxygen was found to be the minimum of all the seven investigated physicochemical parameters of Begu village. Fig. 5 shows the average Physico-chemical parameters of underground water of Mirpur village of Sirsa district. The magnitude of TDS was maximum followed by the Turbidity parameter. The magnitude of dissolved oxygen was found to be the minimum of all the seven investigated physicochemical parameters of Mirpur village. Fig. 6 shows the average Physico-chemical parameters of underground water of Bajenkan village of Sirsa district. The magnitude of Hardness was maximum followed by the TDS parameter. The magnitude of dissolved oxygen was found to be the minimum of all the seven investigated physicochemical parameters of Bajenkan village.

Fig. 7 shows the Hardness (ppm in terms of $\mathrm{CaCO}_{3}$ equivalence) trend of five villages of Sirsa district from June 2020 to May 2021. The hardness was found maximum in Bajenkan village followed by Vaidwala. The hardness was found minimum in Mirpur village. Hence, in terms of hardness underground water of Mirpur village is more suitable as compared to other villages of Sirsa district. Fig. 8 shows the TDS (ppm in terms of $\mathrm{CaCO}_{3}$ equivalence) trend of five villages of Sirsa district from June 2020 to May 2021. The TDS was found maximum in Vaidwala village followed by Begu village. The TDS was found minimum in Mirpur village. 
Hence, in terms of TDS underground water of Mirpur village is more suitable as compared to other villages of Sirsa district.

From Tables 1 to 11 and Figs. 2 to 7, it is concluded that the hardness and TDS level of Mirpur village was found to be a minimum of all five investigated villages of Sirsa district. The hardness of Bajenkan and TDS of Vaidwala was found to be maximum. Hence, the underground water of Bajenkan and Vaidwala was not suitable for drinking and agricultural purposes as compared to other villages of the Sirsa district. The turbidity of Begu and Mirpur villages was found to be higher than other investigated villages. The nitrates, phosphate, and Sulphate content were maximum in the underground water of Begu village and hence is more suitable for agriculture purposes. Hence, based on Physico-chemical studies of underground water of five villages of Sirsa district, the underground water of Mirpur village is more suitable for drinking purposes and the underground water of Begu village is more suitable for agricultural purposes.

\section{Conclusion}

Physicochemical parameters and trace elements of underground water of five villages of Sirsa (Haryana) were estimated by using different titrimetric and instrumental techniques. The sixteen physicochemical parameters like $\mathrm{pH}$, conductivity, TDS, alkalinity, turbidity, heavy metals, BOD, COD, hardness, Nitrates, phosphates, sulfates, elements like $\mathrm{Fe}, \mathrm{Cu}, \mathrm{Cr}, \mathrm{Pb}, \mathrm{Na}$, $\mathrm{K}$, etc. were analyzed. The Water Quality Index and Water Quality Rating were estimated for all the five underground samples of water taken from five different villages of Sirsa district. The hardness and TDS level of Mirpur village was found to be a minimum of all five investigated villages of Sirsa district. The hardness of Bajenkan and TDS of Vaidwala was found to be maximum. Hence, the underground water of Bajenkan and Vaidwala was not suitable for drinking and agricultural purposes as compared to other villages of the Sirsa district. The turbidity of Begu and Mirpur villages was found to be higher than other investigated villages. The nitrates, phosphate, and Sulphate content were maximum in the underground water of Begu village and hence is more suitable for agriculture purposes. Hence, based on Physico-chemical studies of underground water of five villages of Sirsa district, the underground water of Mirpur village is more suitable for drinking purposes and the underground water of Begu village is more suitable for agricultural purposes.

\section{Acknowledgments}

We author of this manuscript are very thankful to the authorities of Guru Kashi University, Talwandi Sabo, Punjab, and Govt. Polytechnic College for Boys, Sirsa for providing necessary lab facilities for this research work.

\section{References}

[1] N. D. Sharma and J. N. Patel, Evaluation of Groundwater quality index of the Urban segments of Surat City, India. Internat. J. of Geology, 4(1), (2010), pp. 1-4.

\section{[2] M. Kumar and R. Kumar, Assessment of Physico-Chemical properties of}


Ground Water in a granite mining area in Goramachia, Jhansi (India). 2(1), (2013), pp. 1924.

[3] Asadullah, K. Nisa and S. I. Khan, Sci., Tech. and Development, 32 (1), (2013), pp. 28-33.

[4] U.M. Qureshimatva, R.R. Maurya, S.B. Gamit, R.D. Patel, and H.A. Solanki, J. Environ. Anal. Toxicol. 5(4), (2014), pp. 288.

[5] N. Jain, Internat. J. of Scientific Res. Engg. \& Tech., 7(1), (2018), pp. 01-09.

[6] D. Kamal, A.N. Khan, M.A. Rahman, F. Ahamed, Pak. J. Biol. Sci. 10(5), (2007), pp. 710717.

[7] A. Begum, S.Y, Noorjahan, C. M., Dawood, S.V. Sharif, "Physicochemical and fungal analysis of a fertilizers factory effluent", Nature Environment \& Pollution Tech. 4(4), (2005), pp. 529-531.

[8] Pawar, Anusha, C., Nair, J. Kumar, N. Jagdav, V. Devi, V. Pawar, C. Smita, "Physicochemical study of groundwork samples from Nacharam Industrial area, Hyderabad, Andhra Pardesh", J. of Aquatic Biology, 21(1), (2006), 118-120.

[9] D. Kallol, S.C. Mohapatra, M. Bidyabati, "Assessment of water quality parameters of the river Brahmani at Rourkela", J. of Indust. Pollution Control, 21(2), (2005), pp.265-270.

[10] R.P. Chavan, R.S. Lokhande, S.I. Rajput, "Monitoring of organic pollutants in Thane creek water”, Nature Environ. \& Pollution Tech., 4(4), (2005), pp. 633-636.

[11] A. Agarwal, F. Rafique, E. Rajesh, and S. Ahmed, "Urban flood hazard mapping using change detection on wetness transformed images", Hydrol. Sci. J., 61, (2016), pp. 816825. https:/doi.org.10.1080/02626667.2014.952638

[12] N. Gupta and et.al., "Physico-Chemical Analysis of Drinking Water Quality from 32 locations in Delhi”, J. of Indian Water Works Association, 9 (2010).

[13] S. Tagy and et al., "Water Quality Assessment in terms of Water Quality Index”, American J. of Water Resources, 1(3), (2013), pp. 34-38.

[14] R. Kavitha and K. Elangovan, "Review article on Groundwater quality characteristics at Erode district, (India)”, I.J.E.S., 1(2), (2010).

[15] S. Mittal and S. Sharma, J. of Environ. Res. \& Amp; Development, 3(1), (2018), pp. 129-136. 
[16] I.K. Ahmad, N.M. Salih, and Y.H. Nzar, "Determination of water quality index (WQI) for Qalyasan stream in Sulaimani city/Kurdistan region of Iraq”, Int. J. Plant Anim. Environ. Sci. 2, (2012), pp. 148-157.

[17] S. Ahmad, S. Farooq, Zahoor-Ul-Islam, A. Khan, Md. W.A. Zaidiand, and H. Matloob, "Impact of urbanization on hydrological regime in Indian cities", J. Environ. Res. Develop. 2, (2017), pp. 594-604.

[18] R.J. Allee, and J. E. Johnson, "Use of satellite imagery to estimate surface chlorophyll-a and Secchi disc depth of Bull Shoals Reservoir, Arkansas, USA", Int. J. Remote Sens. 20, (1999), pp. 1057-1072. https:/doi.org.10.1080/014311699212849

[19] $V$. Amandeep, Identification of land and water regions in a satellite image: a texture-based approach. Int. J. Comput. Sci. Eng. Technol. 1, (2011), pp. 361-365.

[20] R. Bhutiani, F. Ahamad, V. Tyagi, and K. Ram, "Evaluation of water quality of River Malin using water quality index (WQI)”, Environ. Conserv. J. 19, (2018), pp. 191201. https:/doi.org.10.36953/ECJ.2018.191228

[21] R. Bhutiani, and D.R. Khanna, "Ecological status of river Suswa: modeling DO and BOD”, Environ. Monit. Assess. 125, (2007), pp. 183-195.

https:/doi.org.10.1007/s10661-006-9251-4

[22] R. Bhutiani, D.R. Khanna, D.B. Kulkarni, and M. Ruhela, "Assessment of Ganga river ecosystem at Haridwar, Uttarakhand, India with reference to water quality indices", Appl. Water Sci. 6, (2016), pp. 107-113. https:/doi.org.10.1007/s13201-014-02066

[23] R. Bhutiani, D.R. Khanna, B. Tyagi, P.K. Tyagi, and D.B. Kulkarni, "Assessing environmental contamination of River Ganga using correlation and multivariate analysis”, Pollution. 1, (2015), pp. 265-273.

[24] A.K. Bisht, R. Singh, R. Bhutiani, A. Bhatt, K. Kumar, "Water quality modeling of the River Ganga using an artificial neural network with reference to the various training functions", Environ. Conserv. J., 18, (2017), pp. 41-48.

https:/doi.org.10.36953/ECJ.2017.181206

[25] R.M. Brown, N.I. McClelland, R. A. Deininger, and R.G. Tozer, "Water quality index-do we dare?”, Water Sew. Works 117, (1970), pp. 339-343. Census Reports of India 2001. (1971-1991). Available online at https:// censusindia.gov.in/

[26] A. Chabuk, N. Al-Ansari, H.M. Hussain, S. Knutsson, R. Pusch, and J. Laue, 
"Combining GIS applications and method of multi-criteria decision making (AHP) for landfill siting in Al-Hashimiyah Qadhaa, Babylon, Iraq”, Sustainability 9, (2017), pp. 19-32. https:/doi.org.10.3390/su9111932

[27] A. Chauhan, and S. Singh, "Evaluation of Ganga water for drinking purpose by water quality index at Rishikesh”, Uttarakhand, India. Rep. Opin. 2, (2010), pp. 53-61.

[28] C. G. Cude, "Oregon water quality index: a tool for evaluating water quality management effectiveness", J. Am. Water Resour. Assoc. 37, (2001), pp. 125-137. https:/doi.org.10.1111/j.1752-1688.2001.tb05480.x

[29] D.N. Duong, "Waterbody extraction from a multispectral image by spectral pattern analysis”, J. Photogramm Remote Sens. Spat. Inf. Sci. Melb. XXXIX-B. 8, (2012), pp. 248-259. doi:10.5194/isprsarchives-XXXIX-B8-181-2012

[30] S.L. Dwivedi, and V.A. Pathak, "Preliminary assignment of water quality index to Mandakini river”, Chitrakoot. Indian J. Environ. Prot. 27, (2007), pp. 1036-1038.

[31] R.N. Fraser, "Multispectral remote sensing of turbidity among Nebraska Sand Hills Lakes”, Int. J. Remote Sens. 19, (1998), pp. 3011-3016. https:/doi.org.10.1080/014311698214406

[32] S. Girgin, N. Kazanci, and M. Dügel, "Relationship between aquatic insects and heavy metals in an urban stream using multivariate techniques", Int. J. Environ. Sci. Technol. 7, (2010), pp. 653-664. https:/doi.org.10.1007/BF03326175

[33] Y. Icaga, “Fuzzy evaluation of water quality classification”, Ecol. Indic J. Elsevier 7, (2007), pp. 710-718. https:/doi.org.10.1016/j.ecolind.2006.08.002 "Assessment of water quality of polluted lake using multivariate statistical techniques: a case study", Ecotoxicol. Environ. Saf. J. 72, (2009), pp. 301-309. https:/doi.org.10.1016/j.ecoenv.2008.02.024

[35] K.Y. Kondratyev, D.V. Pozdnyakov, and L.H. Pettersson, "Water quality remote sensing in the visible spectrum”, Int. J. Remote Sens. 19, (1998), pp. 957-979. https:/doi.org.10.1080/014311698215810

[36] S. Marale, "Shifting role of ecology in solving global environmental problems: selected practical tools”, Environ. Develop. Sustain. 14, (2012), pp. 869-884. https:/doi.org.10.1007/s10668-012-9362-8

[37] M. Nazeer, and J.E. Nichol, "Combining land sat TM/ETM + and HJ-1 A/B CCD sensors for monitoring coastal water quality in Hong Kong”, IEEE Geosci. Remote Sens. Lett. 12, (2015), pp. 1898-1902. https:/doi.org.10.1109/LGRS.2015.2436899 


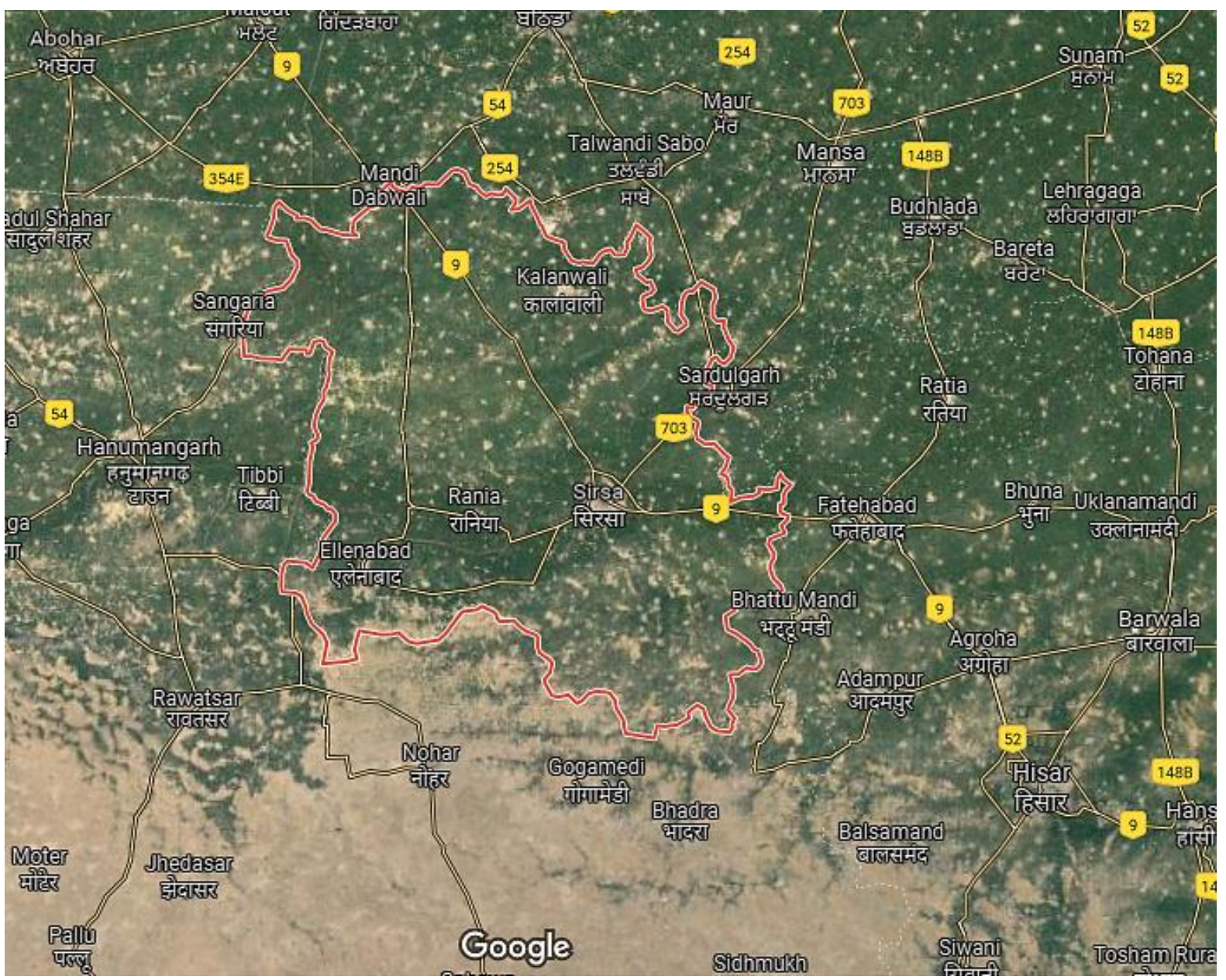

Fig. 1. Satellite image of Sirsa district of Haryana showing Jhopra, Vaidwala, Begu, Mirpur, and Bajekan villages from which underground water was selected for the study. (Source: http://www.maphill.com/india/punjab/3d-maps/satellite-map/) 


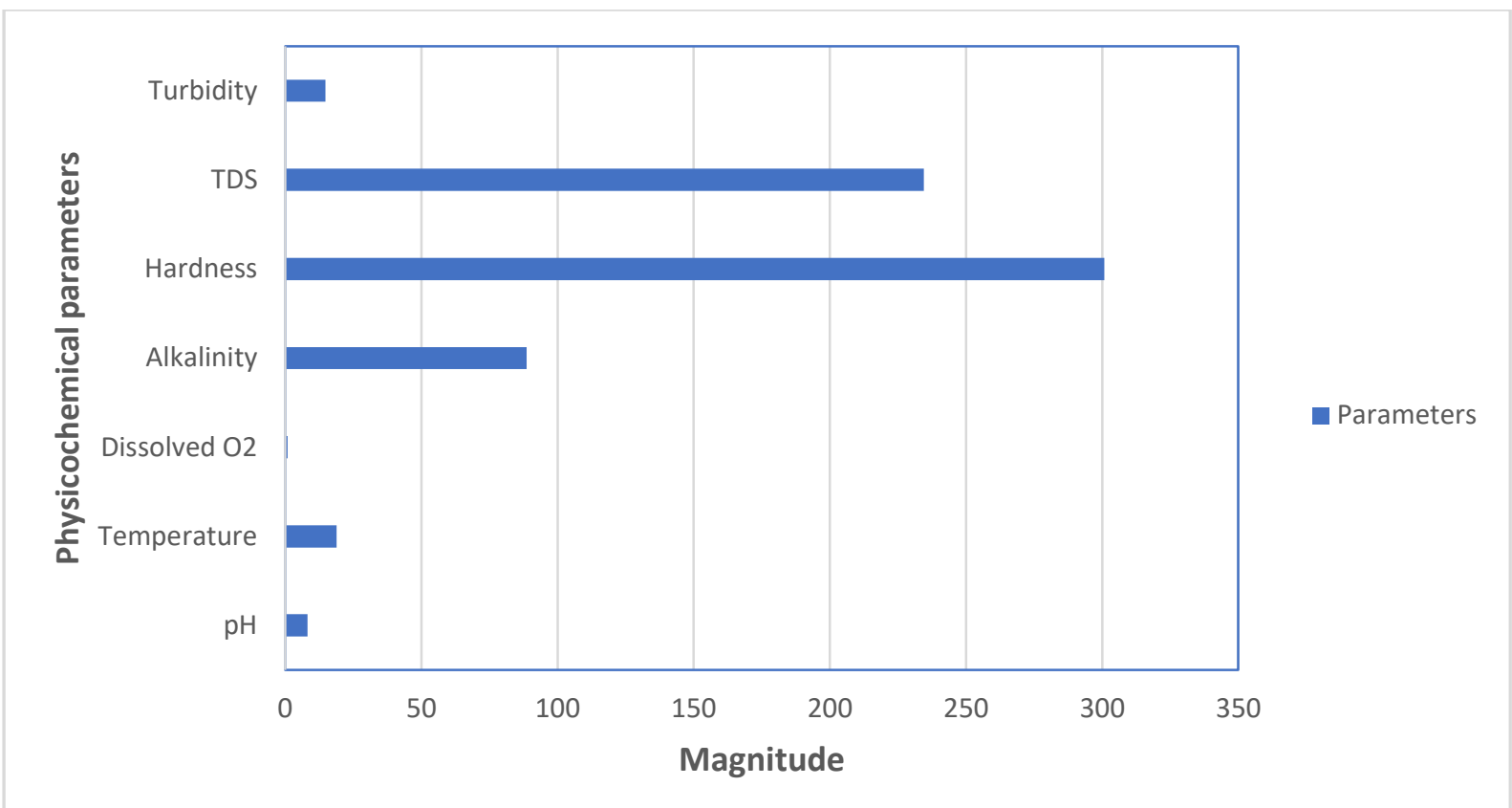

Fig. 2. Average Physico-chemical parameters of underground water of Jhopra village of Sirsa district.

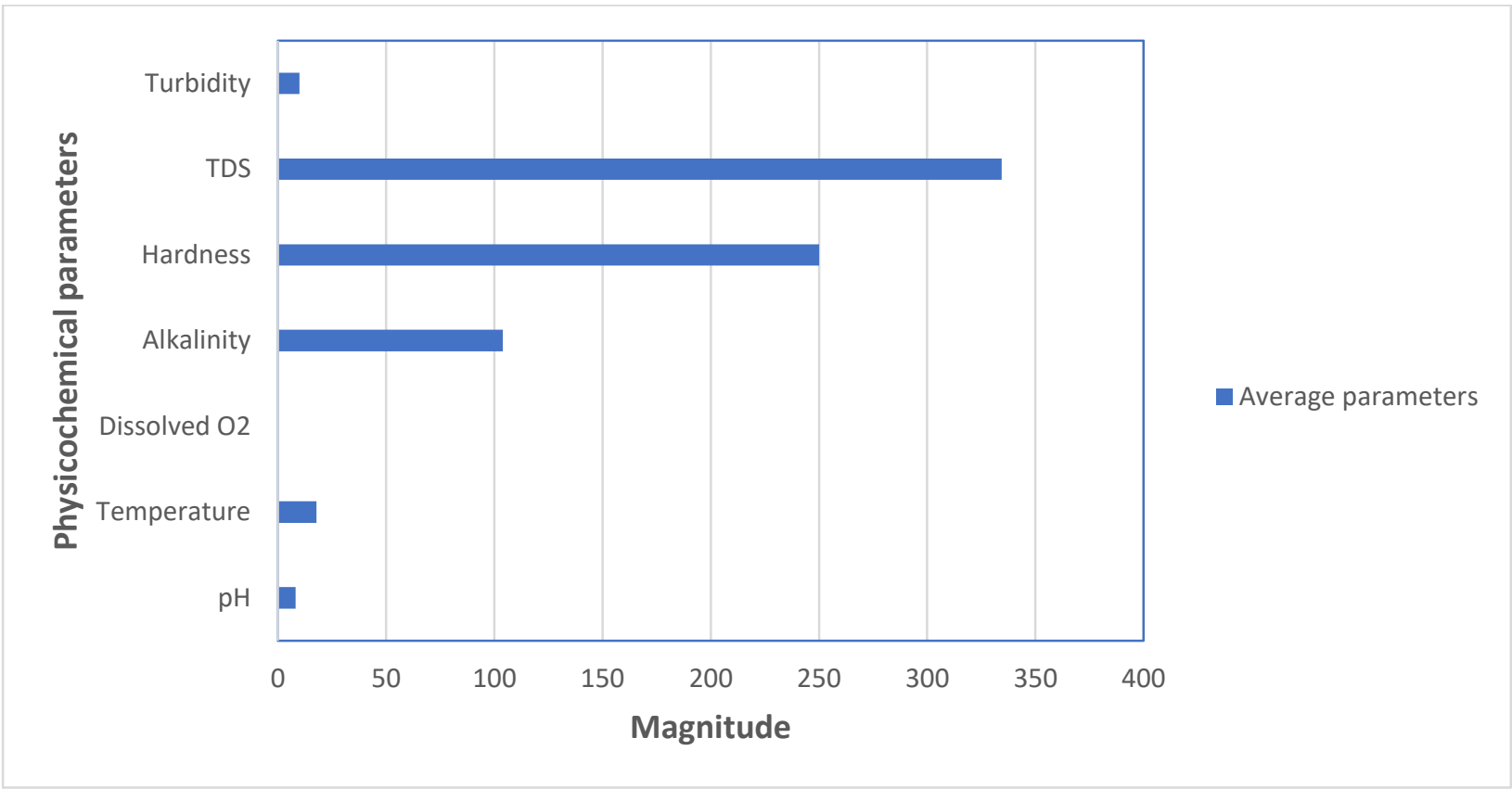

Fig. 3. Average Physico-chemical parameters of underground water of Vaidwala village of Sirsa district. 


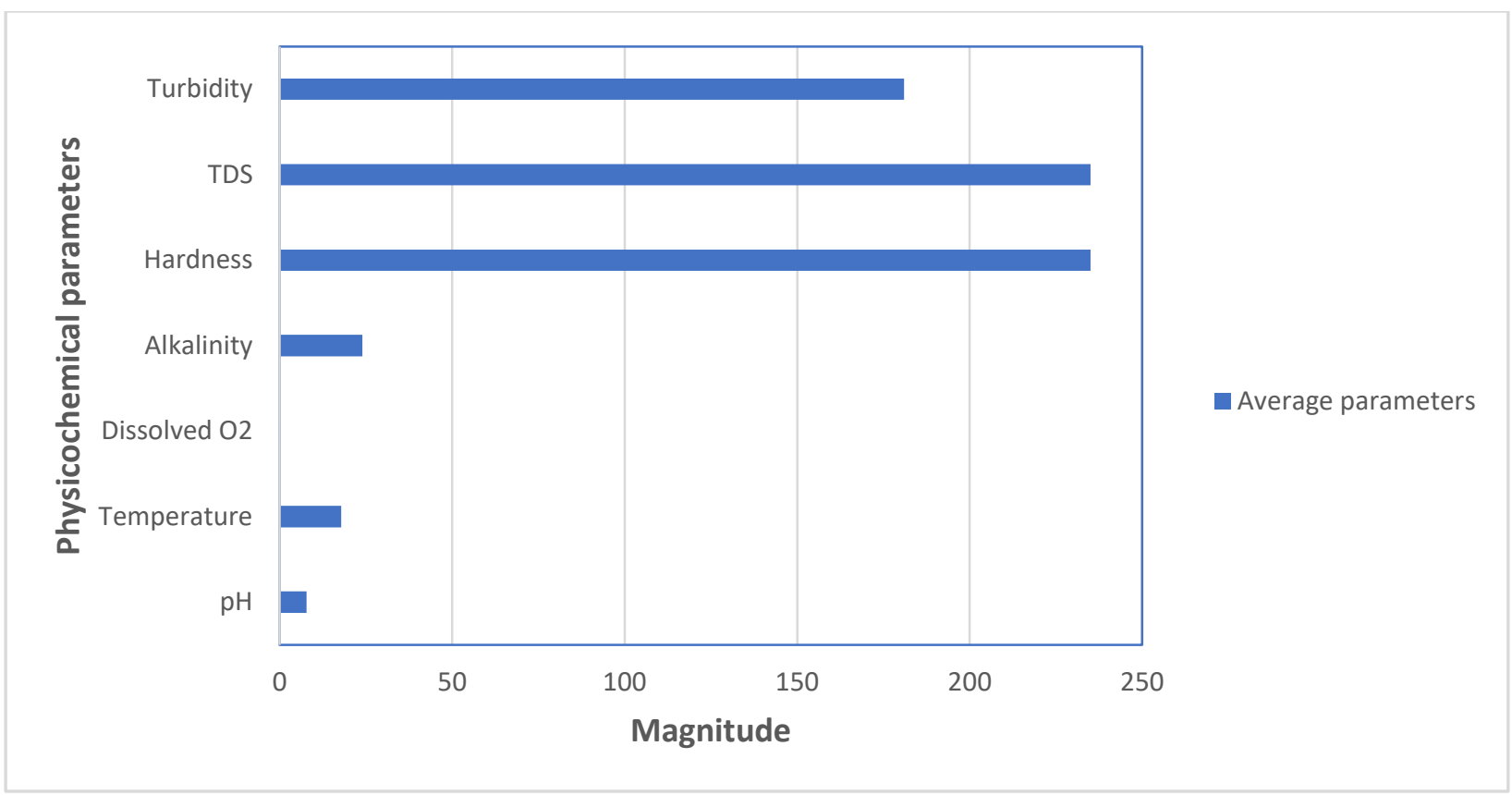

Fig. 4. Average Physico-chemical parameters of underground water of Begu village of Sirsa district.

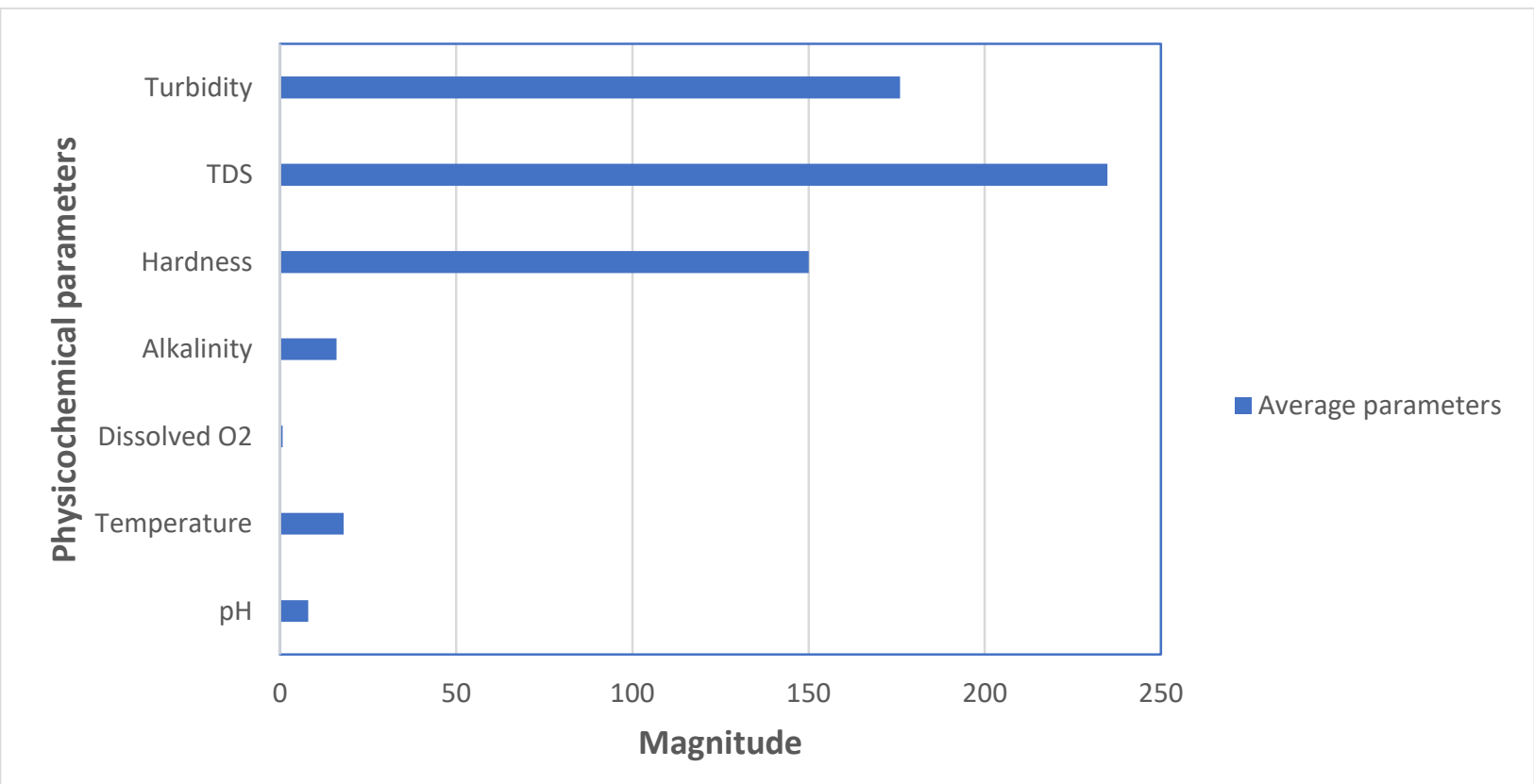

Fig. 5. Average Physico-chemical parameters of underground water of Mirpur village of Sirsa district. 


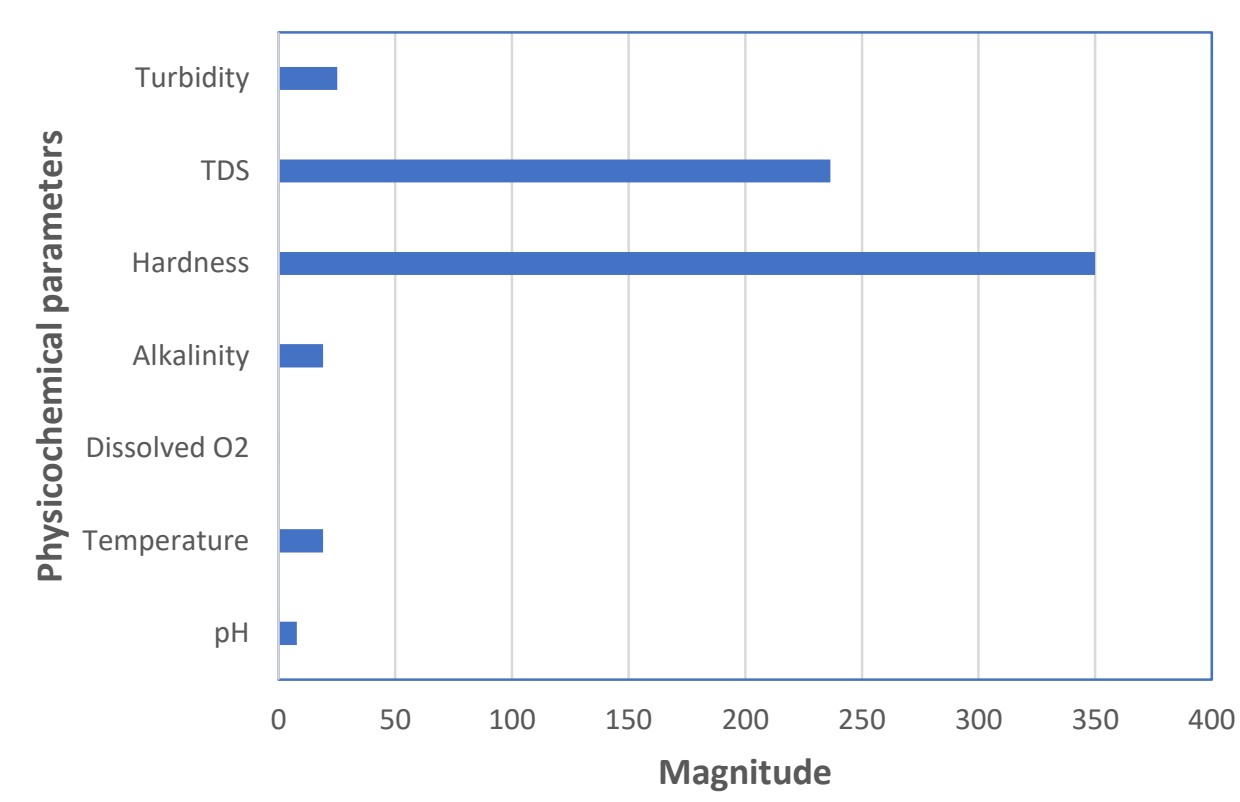

- Average parameters

Fig. 6. Average Physico-chemical parameters of underground water of Bajenkan village of Sirsa district.

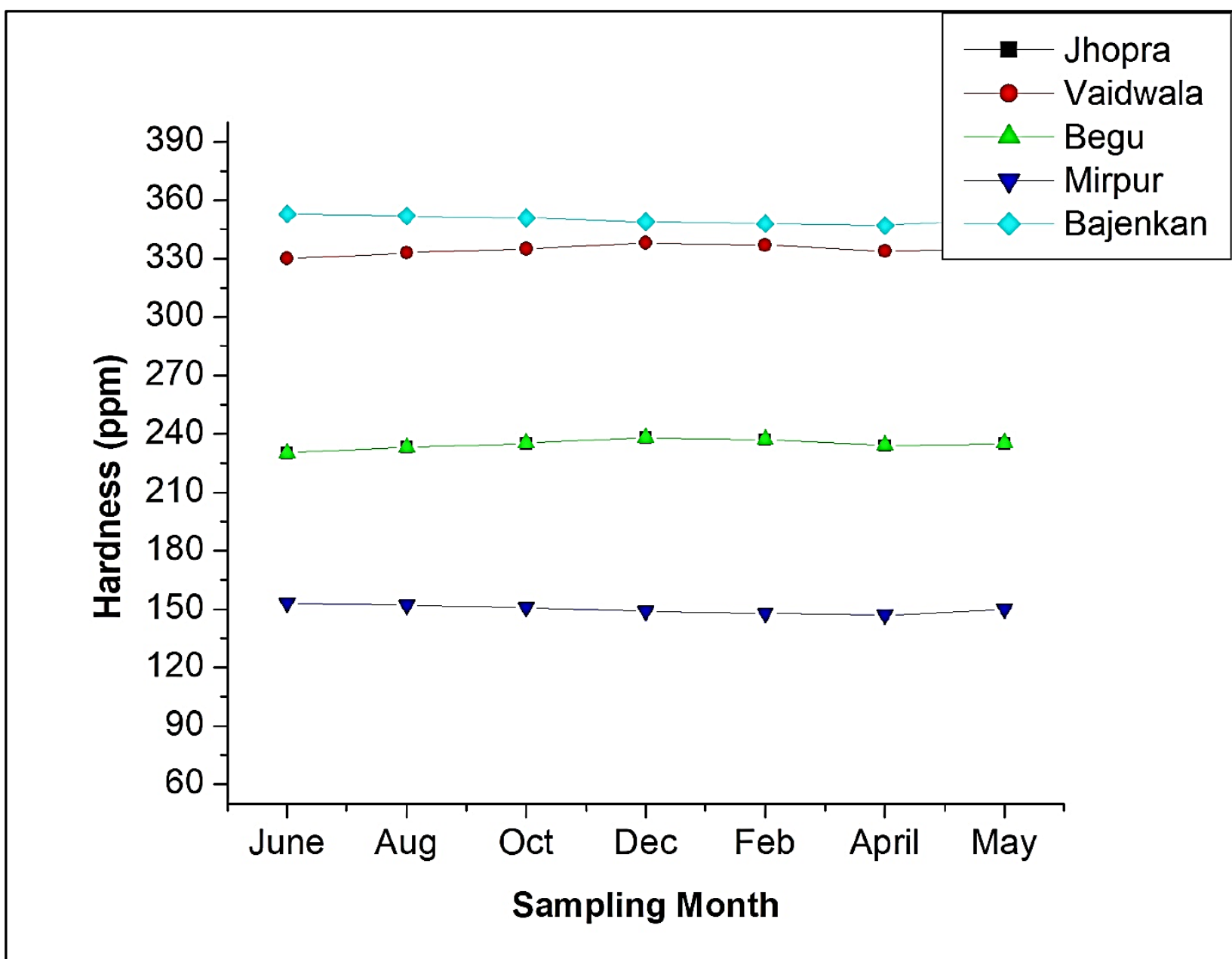

Fig. 7. Hardness (ppm in terms of $\mathrm{CaCO}_{3}$ equivalence) trend of five villages of Sirsa district.

Sampling period from June 2020 to May 2021. 


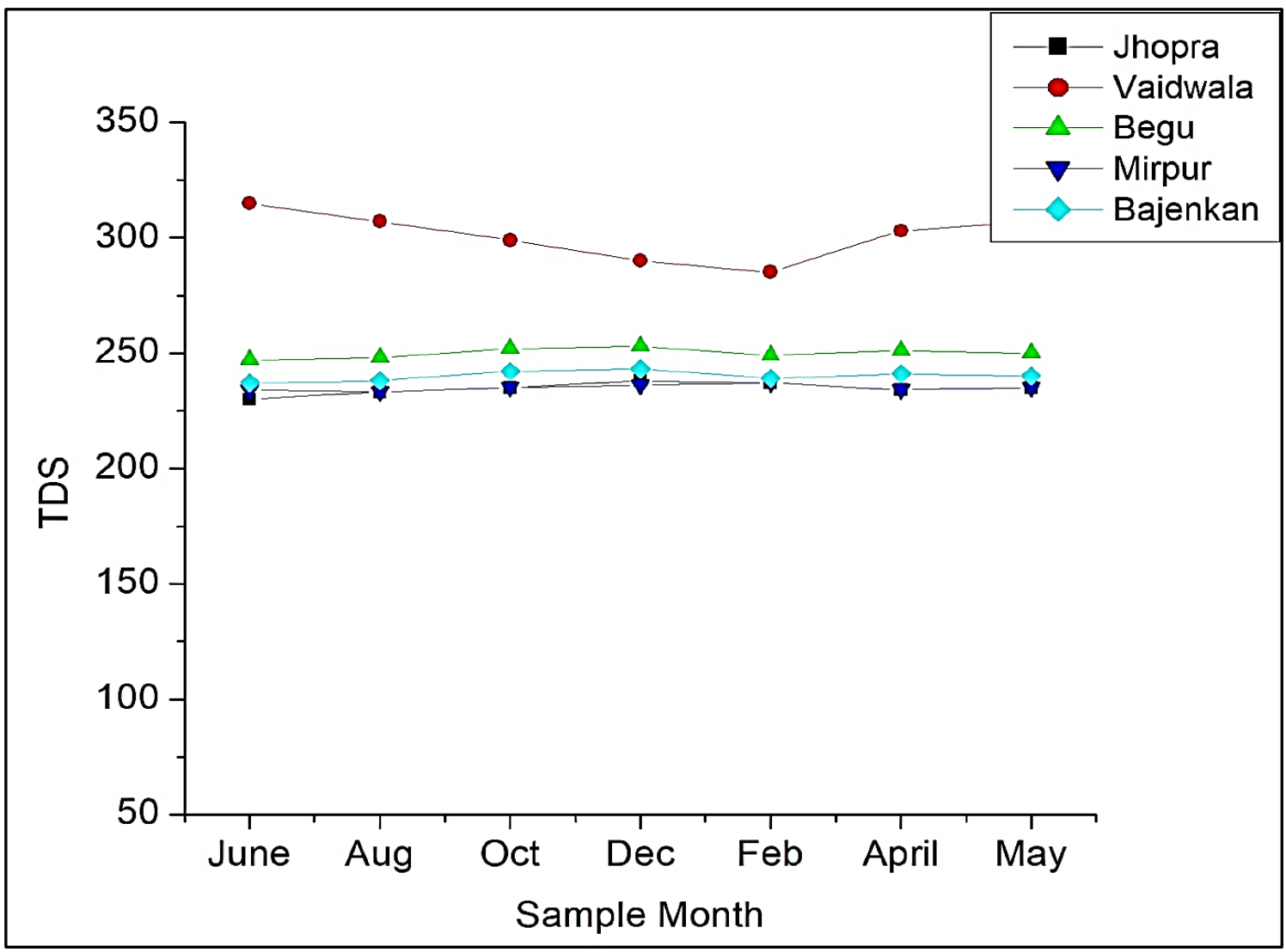

Fig. 8. Total dissolved solid (ppm in terms of $\mathrm{CaCO}_{3}$ equivalence) trend of five villages of Sirsa district. Sampling period from June 2020 to May 2021. 
Table 1. Standard values of Water Quality Index (WQI) and Water Quality Rating (WQR) as prescribed by Central Pollution Control Board (CPCB).

\begin{tabular}{lll}
\hline WQI & Water Quality Rating & Grading \\
\hline $0-25$ & Excellent & $\mathrm{A}$ \\
$26-50$ & Good & $\mathrm{B}$ \\
$51-75$ & Poor & $\mathrm{C}$ \\
$76-100$ & Very poor & $\mathrm{D}$ \\
100 Onwards & Not suitable & $\mathrm{E}$ \\
\hline
\end{tabular}

Table 2. Flame Photometric and UV-Visible spectrophotometric evidence of underground water of five different villages of Sirsa district.

\begin{tabular}{|c|c|c|c|c|c|}
\hline Water Sample & $\begin{array}{l}\mathrm{Na} \\
(\mathbf{p p m})\end{array}$ & $\begin{array}{l}\text { K } \\
(\mathbf{p p m})\end{array}$ & $\begin{array}{l}\text { Nitrate } \\
\text { (at } 220.0 \\
\text { nm) }\end{array}$ & $\begin{array}{l}\text { Phosphate } \\
\text { (at } 690.0 \mathrm{~nm} \text { ) }\end{array}$ & $\begin{array}{l}\text { Sulphate } \\
\text { (at } 420.0 \mathrm{~nm} \text { ) }\end{array}$ \\
\hline Jhopra & 38.7 & 0.37 & 0.0272 & 0.2606 & 0.1946 \\
\hline Vaidwala & 14.5 & 4.9 & 2.2169 & 0.2451 & 0.3518 \\
\hline Begu & 74.2 & 0.94 & 2.7308 & 0.3616 & 1.1313 \\
\hline Mirpur & 14.7 & 0.81 & 0.0769 & 0.3320 & 0.3120 \\
\hline Bajekan & 67.4 & 0.45 & 0.5237 & 0.3497 & 0.7687 \\
\hline
\end{tabular}

Table 3. Physio-chemical average properties ( $\mathrm{pH}$, conductivity, TDS, and Turbidity) of different water samples of five villages of Sirsa district.

\begin{tabular}{lllll}
\hline $\begin{array}{l}\text { Underground } \\
\text { Water Sample }\end{array}$ & $\mathbf{p H}$ & $\begin{array}{l}\text { Conductivity } \\
(\mathbf{m S})\end{array}$ & TDS (ppm) & $\begin{array}{l}\text { Turbidity } \\
(\mathbf{N T U})\end{array}$ \\
Jhopra & 8.10 & 203.0 & 235.3 & 15 \\
Vaidwala & 8.25 & 283.2 & 335.4 & 10.4 \\
Begu & 7.80 & 208.2 & 235.4 & 180.6 \\
Mirpur & 8.08 & 211.2 & 234.8 & 176 \\
Bajekan & 7.73 & 225.4 & 236.5 & 25.2 \\
\hline
\end{tabular}


Table 4. Atomic absorbance spectroscopic (AAS) analysis of water samples of different region of Sirsa district.

\begin{tabular}{lllll}
\hline $\begin{array}{l}\text { Underground } \\
\text { Water Sample }\end{array}$ & Iron $(\mathbf{F e})$ & Copper $(\mathrm{Cu})$ & Chromium $(\mathrm{Cr})$ & Lead $(\mathrm{Pb})$ \\
\cline { 2 - 5 } Jhopra & 0.259 & $\mathrm{ND}$ & $\mathrm{ND}$ & 0.381 \\
Vaidwala & 0.159 & $\mathrm{ND}$ & $\mathrm{ND}$ & 0.384 \\
Begu & 0.159 & $\mathrm{ND}$ & 1.723 & 0.384 \\
Mirpur & 0.110 & $\mathrm{ND}$ & 1.723 & 0.591 \\
Bajekan & 0.259 & ND & ND & 0.594 \\
\hline
\end{tabular}

Note: ND stands for not detected.

Table 5. Volumetric titration analysis (Hardness) of different underground water samples of Five different villages of Sirsa district.

\begin{tabular}{clccc}
\hline S. No. & Water Sample & \multicolumn{3}{c}{ Hardness (CaCO3 equivalence) } \\
\cline { 3 - 5 } & & Total & Permanent & Temporary \\
\hline 1 & Jhopra & 300 & 100 & 200 \\
2 & Vaidwala & 250 & 250 & 0 \\
3 & Begu & 235 & 200 & 150 \\
4 & Mirpur & 150 & 150 & 0 \\
5 & Bajekan & 350 & 300 & 50 \\
\hline
\end{tabular}

Table 6. Volumetric titration analysis (Alkalinity) of different underground water samples of five different villages of Sirsa district.

\begin{tabular}{clccc}
\hline S. No. & Water Sample & \multicolumn{3}{c}{ Alkalinity $(\mathbf{m E q} / \mathbf{L})$} \\
\cline { 3 - 5 } & & p-alkalinity & m-alkalinity & Total \\
\hline 1 & Jhopra & 11 & 8 & 19 \\
2 & Vaidwala & 2 & 12 & 14 \\
3 & Begu & 8 & 14 & 24 \\
4 & Mirpur & 10 & 6 & 16 \\
5 & Bajekan & 10 & 9 & 19 \\
\hline
\end{tabular}


Table 7. Volumetric titration analysis (dissolved oxygen) of different underground water samples of five villages of Sirsa district.

\begin{tabular}{clc}
\hline S. No. & Water Sample & Dissolved $\mathbf{O}_{2}(\mathbf{m l})$ \\
\hline 1. & Jhopra & 0.8 \\
2. & Vaidwala & 0.1 \\
3. & Begu & 0.2 \\
4. & Mirpur & 0.7 \\
5. & Bajekan & 0.3 \\
\hline
\end{tabular}

Table 8. Seasonal variation in seven physiochemical parameters, Water Quality Index (WQI) and standard deviation (SD) of Jhopra village of Sirsa district.

\begin{tabular}{|c|c|c|c|c|c|c|c|c|c|c|}
\hline $\begin{array}{l}\text { Paramete } \\
\mathbf{r}\end{array}$ & $\begin{array}{l}\text { Jun } \\
\text { e } \\
202 \\
0\end{array}$ & $\begin{array}{l}\text { Aug. } \\
2020\end{array}$ & $\begin{array}{l}\text { Oct. } \\
2020\end{array}$ & $\begin{array}{l}\text { Dec. } \\
2020\end{array}$ & $\begin{array}{l}\text { Feb. } \\
2021\end{array}$ & $\begin{array}{l}\text { Apr } \\
\text { il } \\
202 \\
1\end{array}$ & $\begin{array}{l}\text { Ma } \\
y \\
202 \\
1 \\
\end{array}$ & $\begin{array}{l}\text { Averag } \\
\text { e }\end{array}$ & $\begin{array}{l}\text { Standa } \\
\text { rd } \\
\text { deviati } \\
\text { on }\end{array}$ & $\begin{array}{l}\text { W } \\
\text { QI }\end{array}$ \\
\hline pH & 8.4 & 8.1 & 8.0 & 7.8 & 7.7 & 8.5 & 8.6 & 8.15 & 0.07 & 12 \\
\hline Temp. & 25 & 21 & 18 & 16 & 14 & 17 & 21 & 18.8 & 1.7 & 1.4 \\
\hline $\begin{array}{l}\text { Dissolved } \\
\mathrm{O}_{2}\end{array}$ & 0.7 & 0.8 & 1.0 & 1.1 & 0.9 & 0.6 & 0.6 & 0.81 & 0.2 & 21 \\
\hline Alkalinity & 95 & 91 & 85 & 84 & 87 & 85 & 94 & 88.7 & 1.4 & 0.2 \\
\hline Hardness & 315 & 307 & 299 & 290 & 285 & 303 & 307 & 300.8 & 2.4 & 3.4 \\
\hline TDS & 230 & 233 & 235 & 238 & 237 & 234 & 235 & 234.5 & 1.3 & 0.4 \\
\hline Turbidity & 11 & 13 & 15 & 17 & 18 & 16 & 14 & 14.8 & 1.2 & 0.3 \\
\hline
\end{tabular}

Table 9. Seasonal variation in seven physiochemical parameters, standard deviation (SD), and underground Water Quality Index (WQI) of Vaidwala village of Sirsa district.

\begin{tabular}{|c|c|c|c|c|c|c|c|c|c|c|}
\hline Parameter & $\begin{array}{l}\text { Ju } \\
\text { ne } \\
202 \\
0\end{array}$ & $\begin{array}{l}\text { Au } \\
\text { g. } \\
202 \\
0\end{array}$ & $\begin{array}{l}\text { Oct. } \\
2020\end{array}$ & $\begin{array}{l}\text { Dec. } \\
2020\end{array}$ & $\begin{array}{l}\text { Feb. } \\
2021\end{array}$ & $\begin{array}{l}\text { Apr } \\
\text { il } \\
202 \\
1\end{array}$ & $\begin{array}{l}\text { Ma } \\
y \\
202 \\
1\end{array}$ & $\begin{array}{l}\text { Avera } \\
\text { ge }\end{array}$ & $\begin{array}{l}\text { Standar } \\
\text { d } \\
\text { deviatio } \\
\text { n }\end{array}$ & WQI \\
\hline pH & 8.4 & 8.3 & 8.1 & 7.8 & 7.7 & 8.5 & 8.6 & 8.25 & 0.06 & 14 \\
\hline Temp. & 23 & 20 & 18 & 15 & 13 & 16 & 20 & 17.8 & 1.4 & 1.1 \\
\hline Dissolved & 0.1 & 0.1 & 0.14 & 0.17 & 0.19 & 0.15 & 0.17 & 0.15 & 0.4 & 23 \\
\hline $\mathbf{O}_{2}$ & 1 & 3 & & & & & & & & \\
\hline Alkalinity & 95 & 91 & 85 & 84 & 87 & 85 & 94 & 104 & 1.1 & 0.3 \\
\hline Hardness & 245 & 256 & 249 & 258 & 265 & 243 & 257 & 250 & 2.7 & 3.1 \\
\hline TDS & 330 & 333 & 335 & 338 & 337 & 334 & 335 & 334.5 & 1.6 & 0.2 \\
\hline Turbidity & 10 & 11 & 12 & 13 & 8 & 7 & 9 & 10 & 1.6 & 1.5 \\
\hline
\end{tabular}


Table 10. Seasonal variation in seven physiochemical parameters, standard deviation (SD), and underground Water Quality Index (WQI) of Begu village of Sirsa district.

\begin{tabular}{|c|c|c|c|c|c|c|c|c|c|c|}
\hline Parameter & $\begin{array}{l}\text { June } \\
2020\end{array}$ & $\begin{array}{l}\text { Aug. } \\
2020\end{array}$ & $\begin{array}{l}\text { Oct. } \\
2020\end{array}$ & $\begin{array}{l}\text { Dec. } \\
2020\end{array}$ & $\begin{array}{l}\text { Feb. } \\
2021\end{array}$ & $\begin{array}{l}\text { April } \\
2021\end{array}$ & $\begin{array}{l}\text { May } \\
2021\end{array}$ & Average & $\begin{array}{l}\text { Standard } \\
\text { deviation }\end{array}$ & WQI \\
\hline pH & 7.8 & 8.3 & 8.1 & 8.4 & 7.2 & 7.3 & 7.6 & 7.8 & 0.04 & 12 \\
\hline Temperature & 21 & 20 & 18 & 15 & 15 & 16 & 20 & 17.8 & 1.3 & 1.5 \\
\hline Dissolved $\mathrm{O}_{2}$ & 0.21 & 0.23 & 0.24 & 0.17 & 0.19 & 0.15 & 0.17 & 0.2 & 0.5 & 21 \\
\hline Alkalinity & 23 & 24 & 23 & 24 & 26 & 25 & 24 & 24 & 1.2 & 0.5 \\
\hline Hardness & 247 & 248 & 252 & 253 & 249 & 251 & 250 & 250 & 2.4 & 3.3 \\
\hline TDS & 230 & 233 & 235 & 238 & 237 & 234 & 235 & 235 & 1.7 & 0.3 \\
\hline Turbidity & 176 & 175 & 182 & 183 & 184 & 179 & 186 & 181 & 1.4 & 1.4 \\
\hline
\end{tabular}

Table 11. Seasonal variation in seven physiochemical parameters, standard deviation (SD), and underground Water Quality Index (WQI) of Mirpur village of Sirsa district.

\begin{tabular}{|c|c|c|c|c|c|c|c|c|c|c|}
\hline $\begin{array}{l}\text { Paramete } \\
\text { r }\end{array}$ & $\begin{array}{l}\text { Jun } \\
\text { e } \\
2020\end{array}$ & $\begin{array}{l}\text { Aug } \\
\text {. } \\
2020\end{array}$ & $\begin{array}{l}\text { Oct. } \\
202 \\
0\end{array}$ & $\begin{array}{l}\text { Dec. } \\
202 \\
0\end{array}$ & $\begin{array}{l}\text { Feb. } \\
202 \\
1\end{array}$ & $\begin{array}{l}\text { Apri } \\
\text { l } \\
2021\end{array}$ & $\begin{array}{l}\text { May } \\
202 \\
1\end{array}$ & $\begin{array}{l}\text { Averag } \\
\text { e }\end{array}$ & $\begin{array}{l}\text { Standar } \\
\text { d } \\
\text { deviation }\end{array}$ & $\begin{array}{l}\text { WQ } \\
\text { I }\end{array}$ \\
\hline pH & 7.8 & 8.5 & 8.2 & 8.3 & 7.4 & 7.5 & 7.6 & 8.0 & 0.07 & 18 \\
\hline Temp. & 21 & 18 & 17 & 18 & 15 & 16 & 21 & 18 & 1.7 & 7 \\
\hline $\begin{array}{l}\text { Dissolved } \\
\mathrm{O}_{2}\end{array}$ & 0.71 & 0.73 & 0.74 & 0.7 & 0.69 & 0.68 & 0.67 & 0.7 & 0.6 & 19 \\
\hline Alkalinity & 17 & 18 & 19 & 15 & 14 & 13 & 16 & 16 & 1.4 & 6 \\
\hline Hardness & 153 & 152 & 151 & 149 & 148 & 147 & 150 & 150 & 1.8 & 14 \\
\hline TDS & 234 & 233 & 235 & 236 & 237 & 234 & 235 & 234.8 & 1.1 & 3 \\
\hline Turbidity & 176 & 175 & 172 & 173 & 180 & 179 & 181 & 176 & 1.6 & 14 \\
\hline
\end{tabular}

Table 12. Seasonal variation in seven physiochemical parameters, standard deviation (SD), and underground Water Quality Index (WQI) of Bajenkan village of Sirsa district.

\begin{tabular}{lllllllllll}
\hline Parameter & June & Aug. & Oct. & Dec. & Feb. & April & May & Average & Standard WQI \\
& 2020 & 2020 & 2020 & 2020 & 2021 & 2021 & 2021 & & deviation &
\end{tabular}

\begin{tabular}{lllllllllll}
\hline pH & 7.8 & 8.5 & 8.2 & 8.3 & 7.3 & 7.5 & 7.6 & 7.73 & 0.07 & 18 \\
Temp. & 21 & 18 & 17 & 18 & 15 & 16 & 21 & 19 & 1.7 & 7 \\
Dissolved & 0.71 & 0.73 & 0.74 & 0.7 & 0.69 & 0.68 & 0.67 & 0.3 & 0.6 & 19 \\
O2 & & & & & & & & & & \\
Alkalinity & 17 & 18 & 19 & 15 & 14 & 13 & 16 & 19 & 1.4 & 6 \\
Hardness & 353 & 352 & 351 & 349 & 348 & 347 & 350 & 350 & 1.8 & 14 \\
TDS & 237 & 238 & 242 & 243 & 239 & 241 & 240 & 240 & 1.1 & 3 \\
Turbidity & 176 & 175 & 172 & 173 & 180 & 179 & 181 & 25.2 & 1.6 & 14 \\
\hline
\end{tabular}

